\title{
The New High Mountain Locality Ein Qinia with Charophytes in the Northern Israel
}

\author{
Sophia Barinova ${ }^{1, *}$, Roman Romanov $^{2}$ \\ ${ }^{1}$ Institute of Evolution, University of Haifa, Israel \\ ${ }^{2}$ Central Siberian Botanical Garden of the Siberian Branch of the Russian Academy of Sciences, Russia
}

Copyright $(\mathcal{C} 2015$ by authors, all rights reserved. Authors agree that this article remains permanently open access under the terms of the Creative Commons Attribution License 4.0 International License

\begin{abstract}
First study of new locality the Ein Qinia high mountain pool with charophyte algae in the Golan Heights region of Israel has been implemented for revealing of algal diversity and ecological assessment of the water object environment by chemistry and bio-indication methods. Altogether forty two species of algae including one of them macro-algae Chara gymnophylla A.Braun were revealed. Chara, Spirogyra and Oedogonium with attached diatoms and greens were found in massive growth in the studied pool. Bio-indication and chemical variables characterize the pool environment as fresh, low alkaline, with low organic polluted waters, Class II-III of water quality. Water inhabit by forty two taxa of algae and cyanobacteria from five taxonomic divisions. Community prefers eutrophic state of water and photosynthetic type of nutrition. Species composition change from Spirogyra-dominated in 2008-2009 to Oedogonium-dominated in 2012. Index Saprobity S fluctuated between 0.86 and 1.71 whereas Index WESI was very high, always above the 1.0 that reflect high self-purification capacity of the pool ecosystem. We can recommend the Ein Qinia pool for monitoring of natural aquatic object in the Golan Heights as reference site, and Chara gymnophylla as climatic indicator of sunlight intensity.
\end{abstract}

Keywords Charophytes, Ecology, Bio-indication, Pool, Golan Heights, Israel

\section{Introduction}

Freshwater algae distribution is related to the altitude of its habitats as can be seen in the recent references [1]. Altitude also plays the major role in historical species diversity forming process of the charophyte macroalgae [2]. The charophytes prefer alkaline water environments, which form on the carbonates that are widely distributed in the studied region. Therefore, the Eastern Mediterranean environment gives us more chances to find new, unstudied aquatic objects in which charophyte algae can be identified. The charophytes (Charales, Streptophyta) are macroscopic autotrophic algae. The thalli of these algae are one of the largest among algae of continental water ecosystems. The very distinctive feature of charophyte thallus is it very regular morphology due to repeating of nearly identical parts. Charophytes easily colonize habitats in new water bodies as well as ones formed as result of disturbance. They are well-known as pioneer plants i.e. key species in first stages of succession subsequently replaced by angiosperms or filamentous algae especially as a result of eutrophication. In temporal water bodies charophytes are ephemeral or in other words meteoric in appearance. Several species mostly largest ones are perennial and may form communities which are the most stable in clear deep stratifying lakes [3]. The charophytes may be very important components of vegetation in several types of water bodies and may be used as a bio-indicator of ecosystem state, water quality, and ecosystem recovery and reservoir management efficiency. Diversity of this group in the Eastern Mediterranean is studied in initial stage [2]. The most important localities can be found in the mountain areas because especially it can be interesting in the Upper Jordan River basin, which placed in two different slopes of the Jordan Rift Valley [4, 5].

Israel is partly situated in the eastern part of the Mediterranean region and partly within African-Eurasian Dry Zone [6]. Its territory contains several regions with diverse environmental features within its relatively small area. Based on this environmental diversity, we can assume the great diversity of algae of continental water bodies of Israel and in particular charophytes. The history of the study of Israel charophytes has been recently described [2], and we continue finding of new existing localities of charophytes that hitherto not been detected. Close related regions, such as Turkey, also give us charophyte algae new localities that we studied in respect of species diversity and bio-indication of its environment $[7,8]$.

The aim of present study is to identify of charophytes and microscopic algae diversity that studied firstly for this new 
locality in Israel, and to assess the pool environment by bio-indication methods on the base of revealed algal community and water chemistry.

\section{Materials and Methods}

\subsection{Sampling and Laboratory Studies}

Material for this study comes from eighth living and eighth fixed algological samples, fourteen samples of charophytes and eighth samples of water that were collected during four field trips in April 2008, January and April 2009, and March 2012 in the Ein Qinia artificial pool. We have more trips to the site but pool was empty, and we collect samples only when it was watered. We also studied material from the Tel Aviv University herbarium that collected by Dr. Yaakov Lipkin in August 1967 from the Ein Kunie (Ein Qinia) without coordinates.

Algological samples were collected by scratching and scooping, placed in $15 \mathrm{ml}$ plastic tubes, and partly fixed with $3 \%$ neutral formaldehyde solution, as well as partly not fixed and transported to the laboratory in the ice box.

Charophytes were treated with $2-3 \% \mathrm{HCl}$ to remove calcium carbonate. After washing several times with distilled water the material was studied with Nikon stereomicroscope with distilled water the material was air-dried on cover glasses and mounted in Naphrax ${ }^{\circledR}$. The structure elements were observed with Nikon light microscope (LM) and Leica stereomicroscope with digital camera 520 DC, DinoLight camera in the Institute of Evolution, University of Haifa and the Central Siberian Botanical Garden with help of international handbooks $[9,10]$. Charophyte and microscopic algae abundance were assessed as abundance scores according 6-score scale [11]. Herbarium specimens were deposited in the Institute of Evolution, University of Haifa (IEUH), and the Central Siberian Botanical Garden, Novosibirsk (NS).

Algae and cyanobacteria were studied with the SWIFT and OLYMPUS dissecting microscopes under magnifications $740 x-1850 x$ from three repetitions of each sample and were photographed with the Axiocam DC OMAX A35100U. The diatoms were prepared by the peroxide technique [12] modified for glass slides [13] and were placed in the Naphrax ${ }^{\circledR}$ resin from two repetitions of each sample.

Temperature was measured with a thermometer. Water $\mathrm{pH}$, conductivity (EC), and TDS were measured with HANNA HI 9813-5. Chlorides and sodium percentages were determined with "Handheld Refractometers X-Series Sodium Chloride" with three repetitions. The concentration

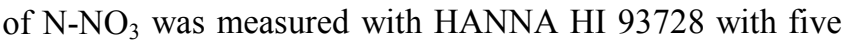
repetitions.

Index saprobity s was calculated according to [14]. Index of aquatic ecosystem sustainable was calculated according to $[11,15]$ as $(1)$ :

$$
\text { WESI }=\text { Rank S } / \text { Rank N-NO } .
$$

Where: Rank S - rank of water quality on the Sladeček's indices of saprobity; Rank N-NO 3 - rank of water quality on the nitric-nitrogen concentration (Table 1).

If WESI is equal to or larger than 1, the photosynthetic level is positively correlated with the level of nitrate concentration. If the WESI is less than 1, the photosynthesis is suppressed presumably according to toxic disturbance [11].

\subsection{Description of the Study Site}

The Ein Qinia artificial pool is placed in the left slope of the Wadi Shatr spring the right tributary of the Saar stream that is left tributary of the Upper Jordan River in the Northern part of Israel, above the Ein Qinia settlement in the Golan Heights (Figures 1,2) on altitude about $937 \mathrm{~m}$ above sea level with coordinates $33^{\circ} 14^{\prime} 28 \mathrm{~N}, 35^{\circ} 44^{\prime} 29 \mathrm{E}$. It is small, rectangular, about $6 \times 15 \mathrm{~m}$ and up to one $\mathrm{m}$ deep (Figure 2), filled by natural rainy waters during winter. While the Saar and Ein Shatr streams are winter streams only, the Ein Qinia pool is also seasonal but we have a data from the Y. Lipkin herbarium that it has been watered in August 1967. During four field trips in the rainy season we explore decreasing of water level in the pool as show in Figures 3 (2008), 4 (2009), and 5 (2012). Pool is used for the agriculture purposes because the local druses have gardens on the slope of the mountains. Therefore, pool water that collected during rainy period is used up to early summer and all dry season in the last years the pool is empty.

Climatic condition of the Ein Shatr spring basin area [16] is warm and temperate in Ein Qinia. There is more rainfall in the winter than in the summer. The average annual temperature is $14.9^{\circ} \mathrm{C}$. The average annual rainfall is 789 $\mathrm{mm}$. The driest month is July, with $0 \mathrm{~mm}$ of rainfall. With an average of $188 \mathrm{~mm}$, the most precipitation falls in January. The warmest month of the year is August, with an average temperature of $22.9^{\circ} \mathrm{C}$. January has the lowest average temperature of the year about $5.8^{\circ} \mathrm{C}$. During the year, the average temperatures vary about $17.1^{\circ} \mathrm{C}$. 


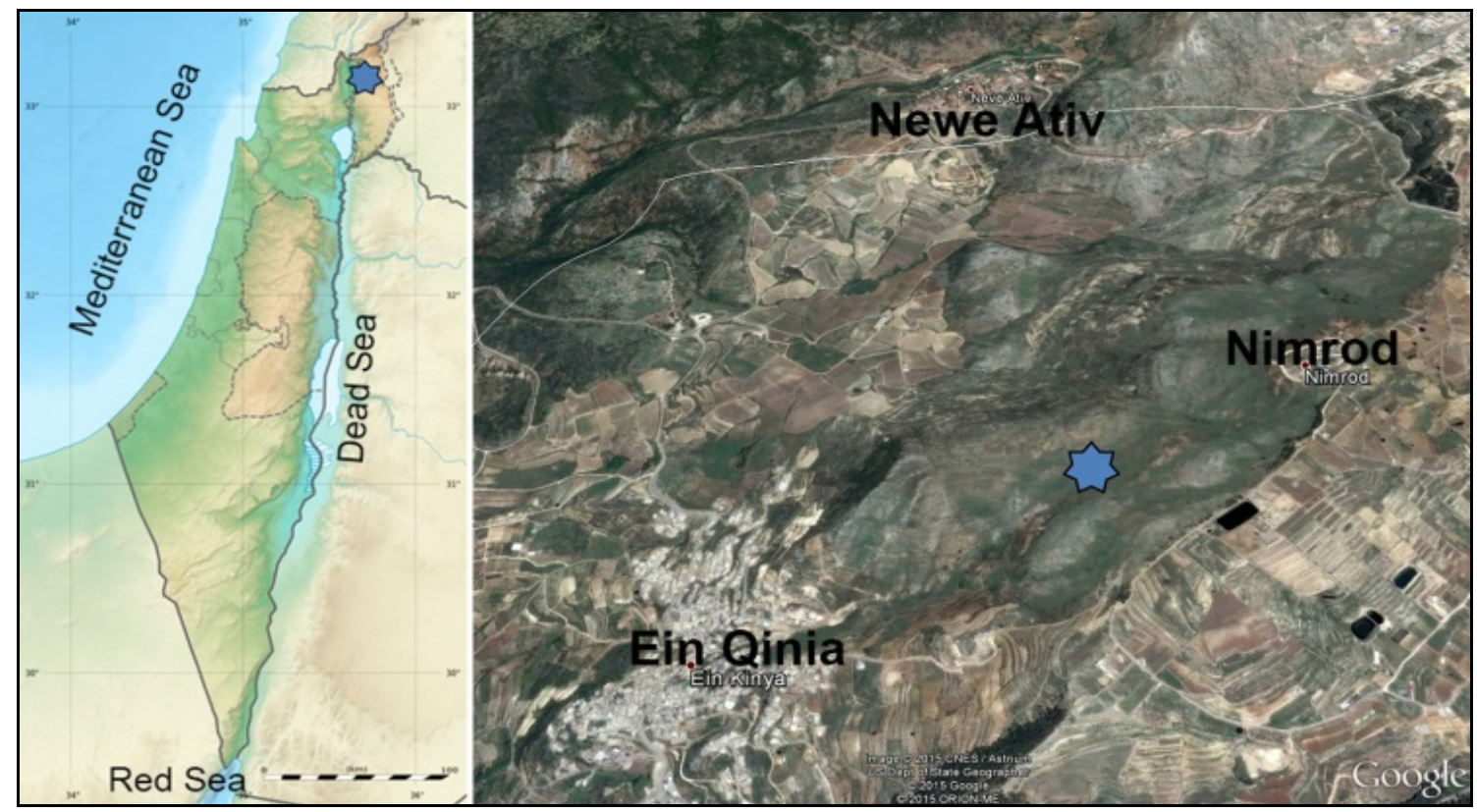

Figure 1. The Ein Qinia Pool locality (blue star) in the Golan Heights of Northern Israel.

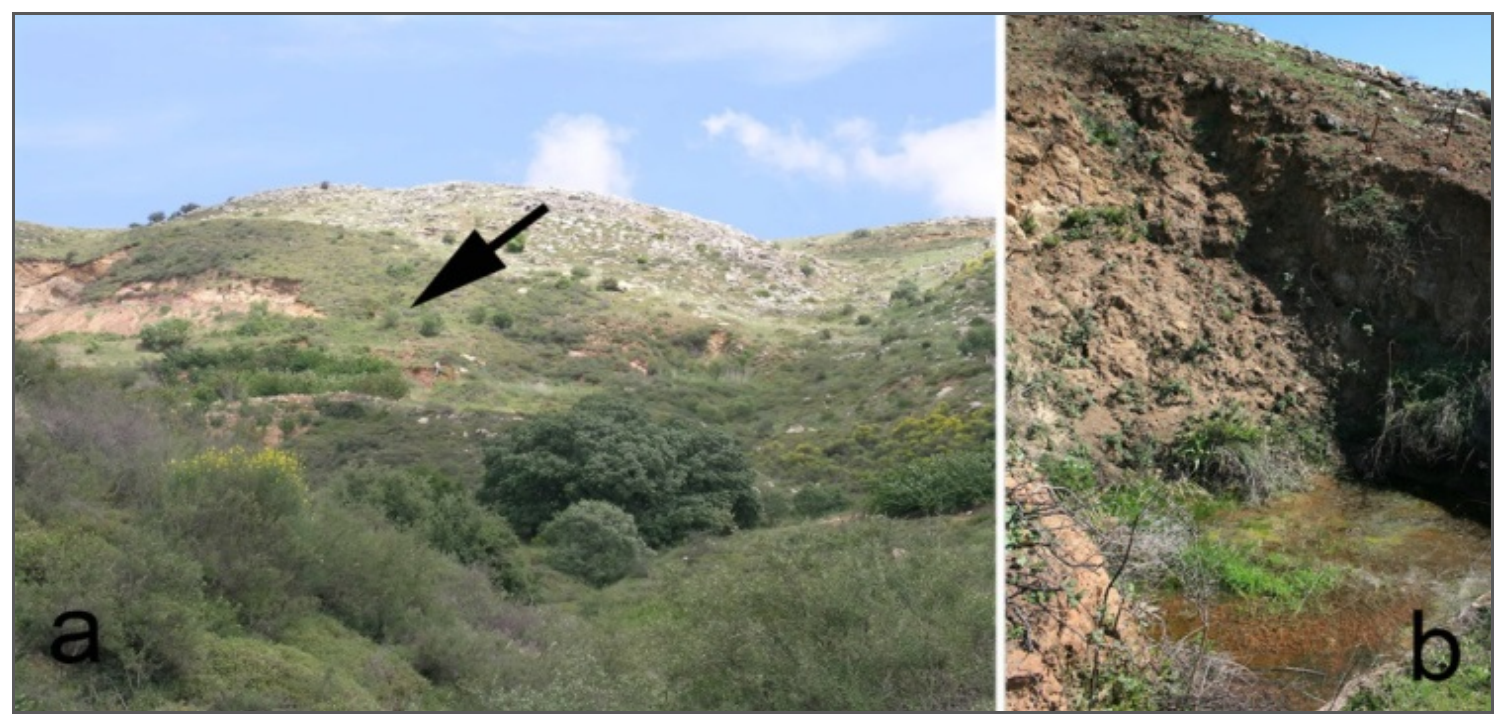

Figure 2. Ein Qinia Pool locality near the top of the mountains (pointed by black arrow) (a, 2009) looks like small artificial pool (b, 2012)

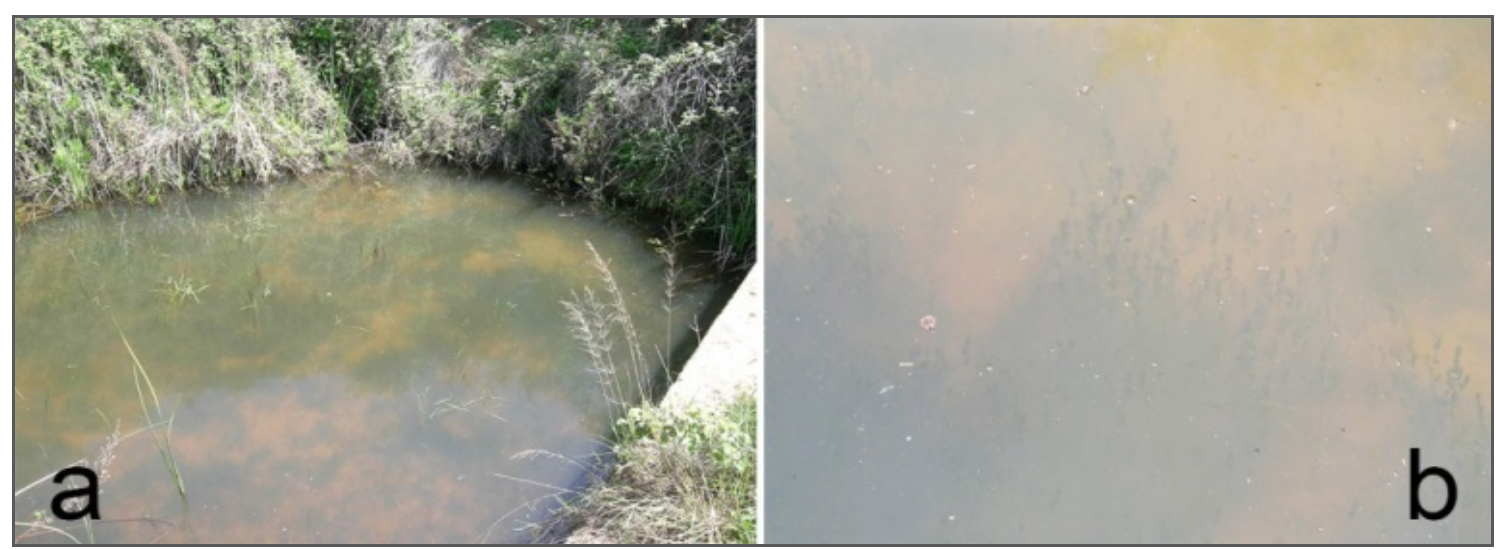

Figure 3. Ein Qinia Pool: a, watered pool in 2008; b, charophytes population grow in April 2008 


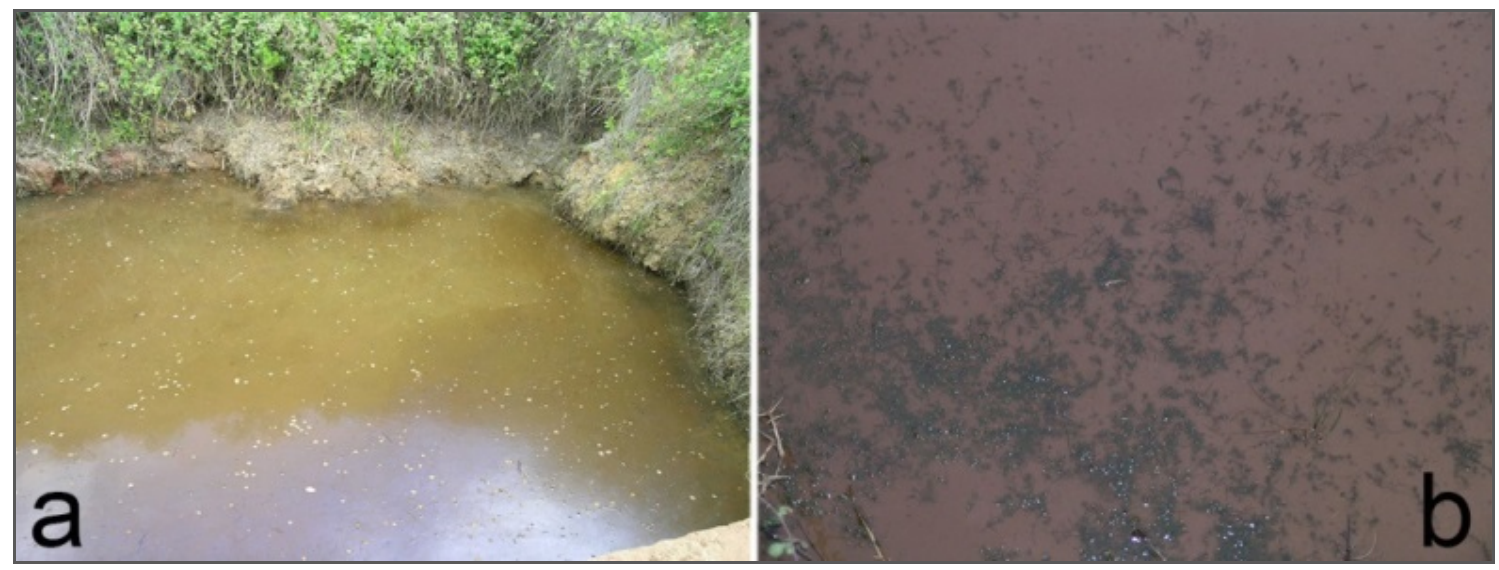

Figure 4. Ein Qinia Pool: a, watered pool in 2009; b, charophytes population grow in January 2009
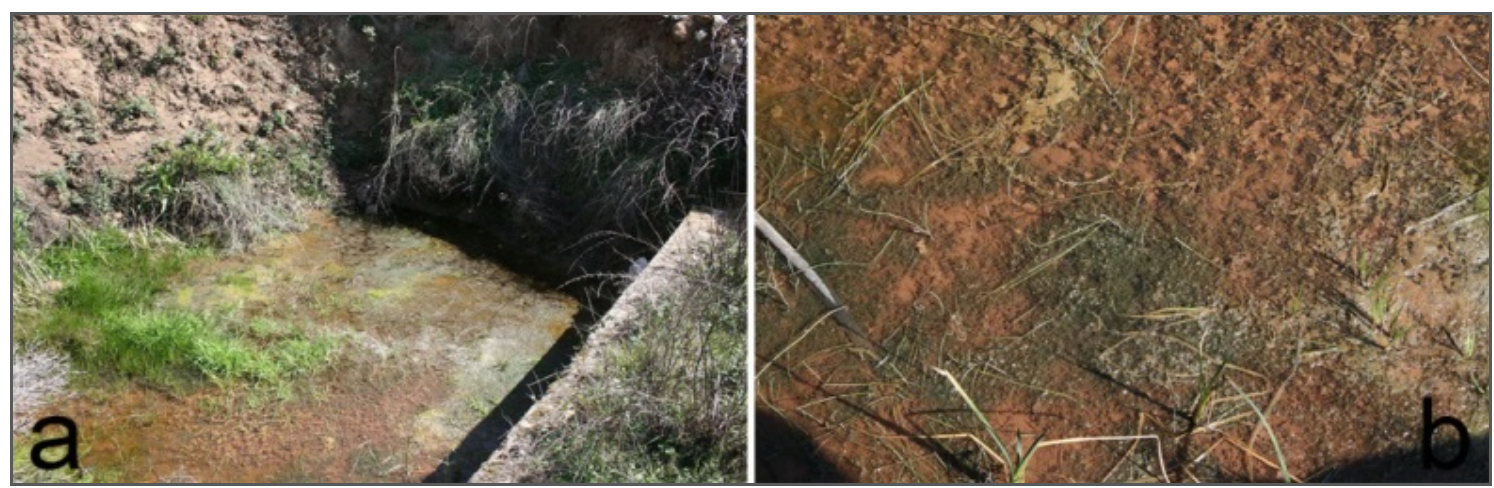

Figure 5. Ein Qinia Pool: a, watered pool in 2012; b, charophytes population grow in March 2012

Table 1. Chemical and biological variables of the Ein Qinia pool in April 2008, January 2009, and March 2012 with Minimum (Min), Maximum (Max), and Standard Deviation (SD) of the data.

\begin{tabular}{|c|c|c|c|c|c|c|}
\hline Date & 2008 & 2009 & 2012 & Min & Max & SD \\
\hline${\mathrm{E}, \mathrm{msm} \mathrm{cm}^{-1}}^{-1}$ & 0.467 & 0.41 & 0.19 & 0.19 & 0.53 & 0.12 \\
\hline $\mathrm{N}-N O_{3}, \mathrm{mg} \mathrm{l}^{-1}$ & 0 & n.a. & 0 & 0 & 0 & 0 \\
\hline $\mathrm{pH}$ & 7.43 & 8.1 & 7.9 & 6.7 & 8.1 & 0.48 \\
\hline $\mathrm{TDS}, \mathrm{mg} \mathrm{l}^{-1}$ & 337.8 & 294 & 137 & 137 & 385 & 87.27 \\
\hline $\mathrm{T}^{\circ} \mathrm{C}$ & 17.4 & 17.5 & 18.4 & 16.0 & 19.5 & 1.61 \\
\hline No of Species & $8-13$ & 9 & $9-35$ & 8 & 35 & 11.45 \\
\hline Index Saprobity S & $0.86-1.73$ & $1.21-1.44$ & $1.33-1.52$ & 0.86 & 1.73 & 0.30 \\
\hline Index WESI & $2-4$ & - & $3-4$ & 2 & 4 & 0.96 \\
\hline
\end{tabular}

\section{Results and Discussion}

\subsection{Chemical Composition of the Pool Water}

Chemical variables were measured in rainy season only because in summer the pool was dry. The pool water is used for agricultural purposes and periodically pool was empty even in winter. Table 1 show that environment variables are fluctuated in small range and reflected fresh, low alkaline to neutral, low to temperate temperature, and low polluted waters $[11,15]$ with low nitrates concentration. Index of saprobity $\mathrm{S}$ is fluctuated between 0.86 and 1.73 that corresponds to Water Quality Class II-III ranges during the rainy period.

\subsection{Diversity and Ecology of Algae}

We revealed forty two taxa of algae and cyanobacteria (Table 2) diversity of which is rather constant during the sampling dates. Studied pool bottom was covered by macrophyte alga Chara gymnophylla (Figures 3-5), which has highest thalluses when the water level was high (Figures 3-5). Black basal part of thallus in Figures $6 a$ and $6 \mathrm{c}$ reflect anoxia environment in the pool sediments.

Morphological description of specimens from 2012 collection represent thalluses that unincrusted in all apical parts to moderately calcite-incrusted plants were mostly sterile with branchlets mostly undifferentiated (Figures 6, 7a). Stem cortex is diplostichous mostly isostichous to 
slightly aulocanthous or rarely to slightly tylacanthous (Figures 7d, e). Spine cells were ellipsoid, solitary and spreading. Stipulodes were diplostephanous, ellipsoid, obtuse. Branchlets were 6-celled, ecorticate and had one or two nodes with 2 unilateral bract cells unequal in length in the same node and very rare with immature gametangia at the first node only (Figures 7a-c). Gametangia were conjoined and solitary with protandry. We referred these specimens to Chara gymnophylla.

Specimens from Y. Lipkin collection are moderately calcite-incrusted plants were richly fertile (Figure 8a). Stem cortex was diplostichous aulocanthous to isostichous with solitary spreading ellipsoid spine cells (Figures 8e, f). Stipulodes were diplostephanous, ellipsoid, obtuse (Figure $8 d)$. Branchlets had 1-2, exceptionally 3 lowest corticated segments or were ecorticate with nodes which had unilateral bract cells and gametangia (Figures $8 \mathrm{~b}, \mathrm{c}$ ). Completely ecorticate brachlets had up to 3 nodes with unilateral bract cells. The fructified single nodes between ecorticate cells were rather commonly situated above 1 or usually 2 nodes adjacent or situated between corticated segments. Bract cells were 2-3-fold longer than oogonium, nearly equal or frequently significantly longer which strongly resembled branchlets of Chara vulgaris var. longibracteata (Kütz.) J. Gr. et B.-Webst. Gametangia were conjoined and solitary. Initially these specimens were identified as Chara gymnophylla due to common presence both of fructified nodes between ecorticate segments and completely ecorticate branchlets with nodes. The differentiated character for C. gymnophylla and C. vulgaris suggested by [17] was at least a single fructified node between ecorticate segments of branchlet above 1-2 fructified nodes between or adjacent to corticated segments within a branchlet. Therefore, it seems correct to refer specimens studied to form of $C$. vulgaris closely approaching C. gymnophylla.

Charophyte species Chara gymnophylla that we found in the Ein Qinia pool has wide distribution in Israel [2] over Mediterranean climatic zone [18] and some climatic similar dry regions [19]. Species is simply separated from the other members of the genus Chara as we revealed by Amplified fragment length polymorphism (AFLP) analysis [20]. C. gymnophylla in Israel preferred distribution in the northern part and inhabited the streaming and standing waters of the water bodies in the Mediterranean and Irano-Turanian Realm.

Beside of massive grows of Chara, other identified species corresponds to five taxonomic divisions (Table 2) from which the mostly were diatoms (Figure 8) that attach macrophytes, charophytes and bottom in the pool. The most abundant in communities were diatom species Fragilariforma exigua, Gomphonema clavatum, Navicula rhynchocephala, and Rhopalodia gibba over the all studied period. Chlorophyta algae show plasticity and change its participation in community from Spirogyra sp. as free floating form in 2008 and 2009 to Oedogonium sp. as attached form on charophytes plants in 2012. Green epiphytic algae Aphanochaete repens was found on the charophytes thalluses in massive grows in 2012 also. Because epiphytes attack the plants when the environment is in unfavorable condition for charophytes, we can assume that decreasing of water level in the pool is stressed charophytes whereas other algae in community are flourishing.

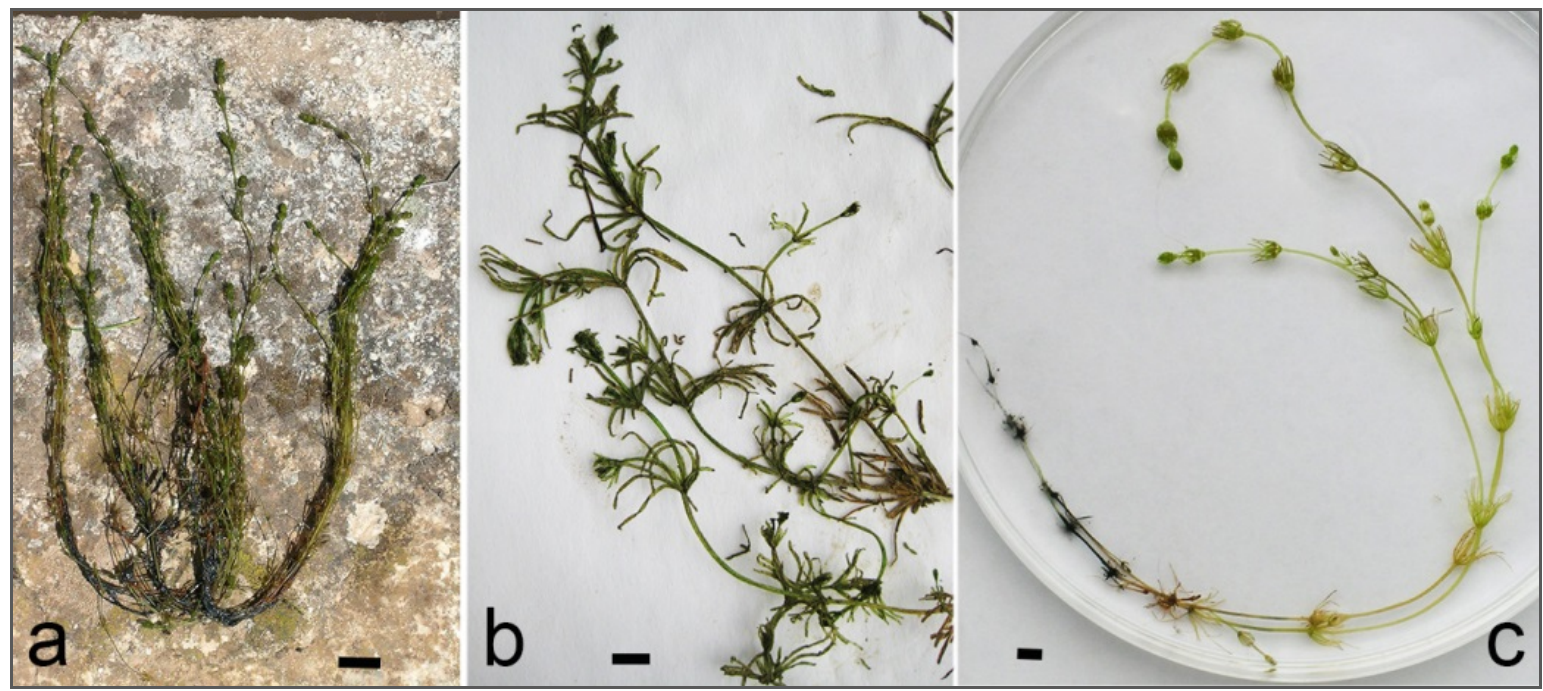

Figure 6. Chara vulgaris (gymnophylla) in Ein Qinia Pool: a - total view of thallus on the pool dam in 2008; b - thalluses in herbarium in 2012; c thalluses in the petri, seen black basis of thallus that evidenced of anoxia in the pool sediments in 2012 . Scale bar: a $-2 \mathrm{~cm}, \mathrm{~b}, \mathrm{c}-1 \mathrm{~cm}$. 


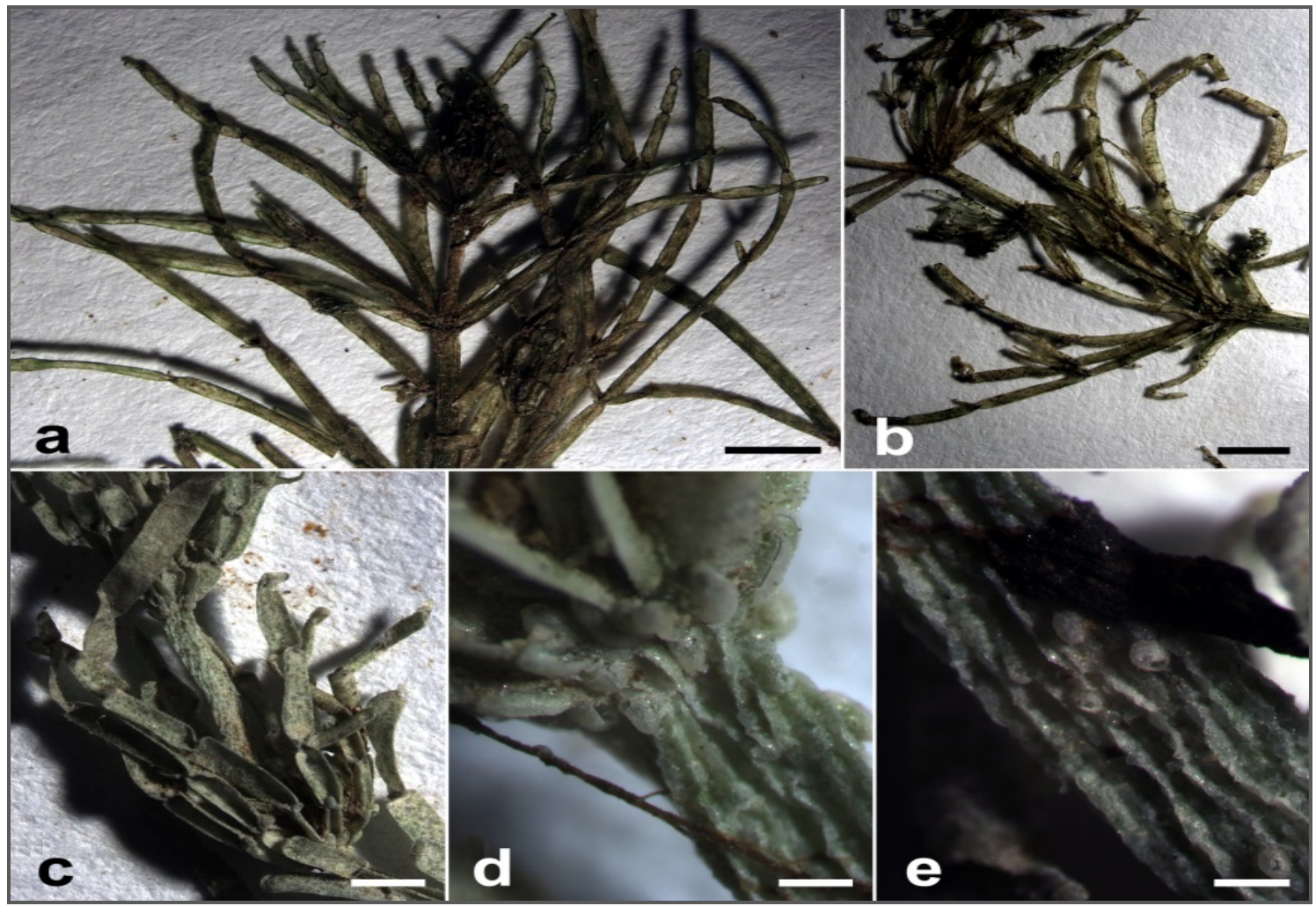

Figure 7. Chara gymnophylla in Ein Qinia Pool in 2012: a - apical part of thallus; b, c - whorls of branchlets; $\mathrm{d}$ - stipulodes and stem cortex; e-stem cortex. Scale bar: a, b - $2 \mathrm{~mm}, \mathrm{c}-1 \mathrm{~mm}, \mathrm{~d}, \mathrm{e}-0.2 \mathrm{~mm}$.
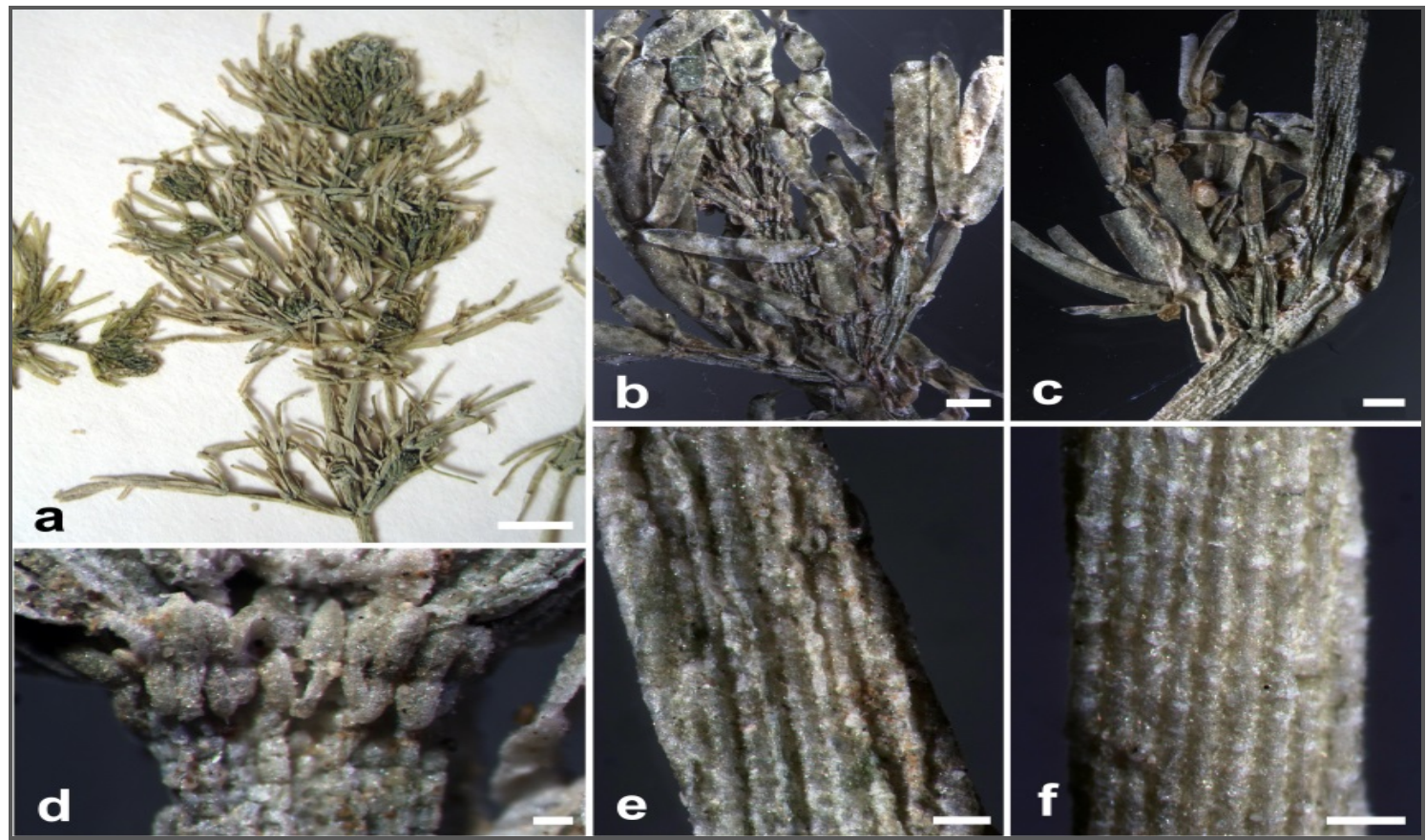

Figure 8. Chara vulgaris in Y. Lipkin collection from the pool near the Ein Qinia: a - apical part of thallus; b, c- whorls of branchlets; $d$ - stipulodes; e, f - stem cortex. Scale bar: - a, b, c $-0.5 \mathrm{~mm}, \mathrm{~d}, \mathrm{e}, \mathrm{f}-0.2 \mathrm{~mm}$. 


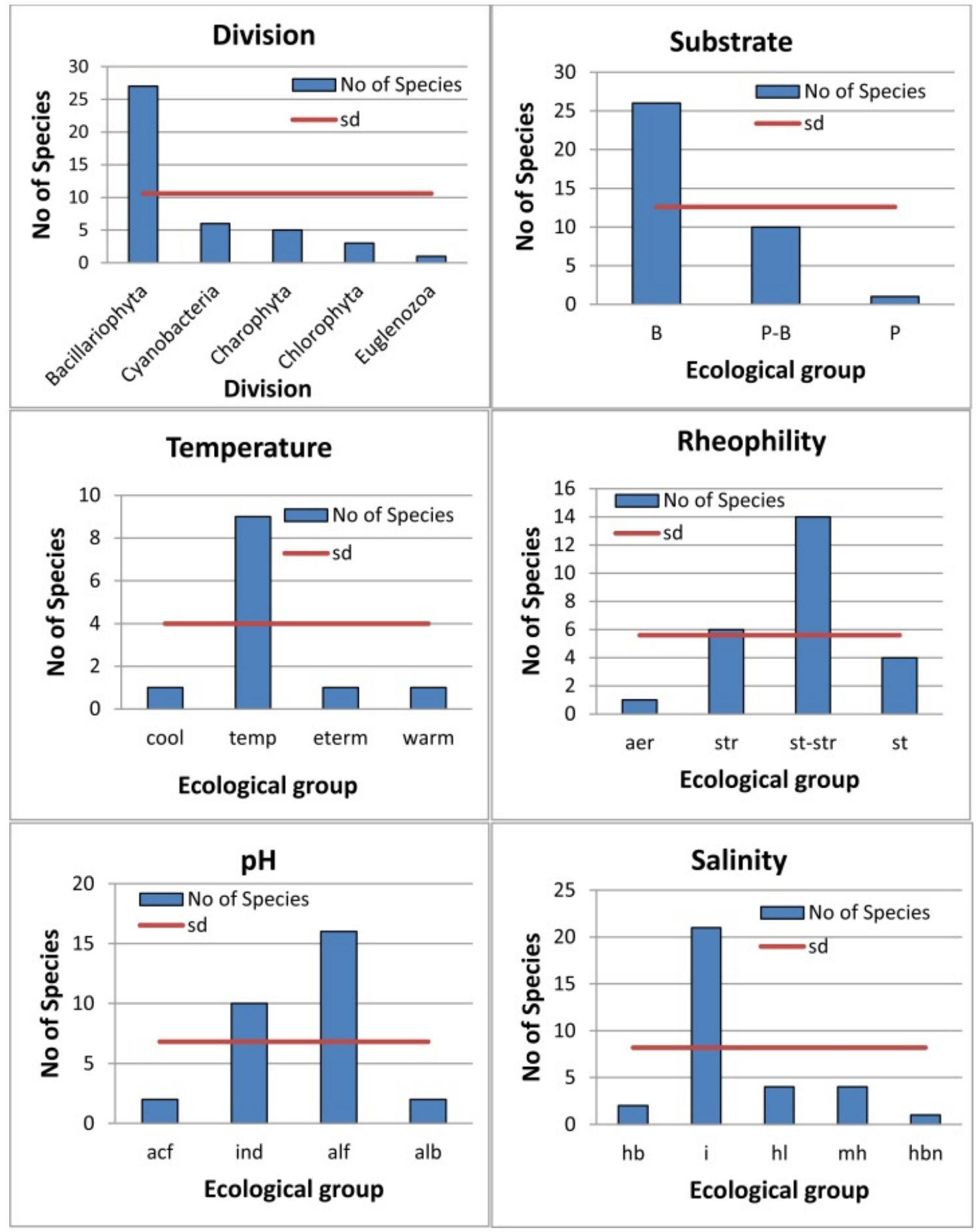

Figure 9. Taxonomic composition of algal communities and bio-indication plots in the Ein Qinia pool. Abbreviation as in Table 2. 


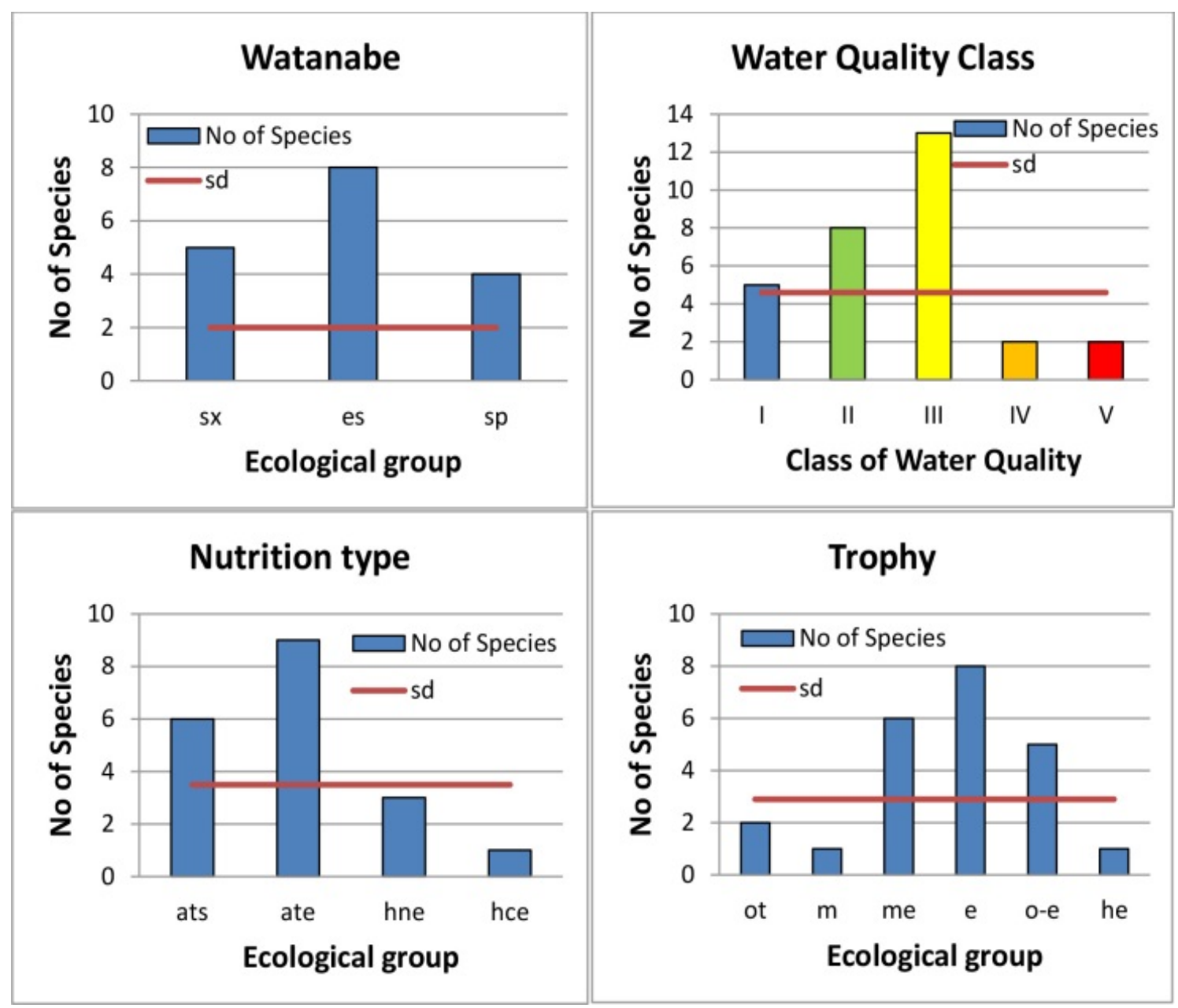

Figure 10. Bio-indication plots of the Ein Qinia pool on the base of algal community. Abbreviation as in Table 2. Water Quality Classes indicators are given in EU color code.

Table 2. Algal diversity with abundance scores and species ecological preferences (according to [11,22]) in the Ein Qinia pool in 2008-2012

\begin{tabular}{|c|c|c|c|c|c|c|c|c|c|c|c|}
\hline Taxa & Score & $\mathrm{Hab}$ & $\mathrm{T}$ & Rhe & $\mathrm{pH}$ & Sal & Sap & $\mathrm{D}$ & Aut-Het & Tro & pH-range \\
\hline \multicolumn{12}{|l|}{ Cyanobacteria } \\
\hline Anabaenopsis sp. & 1 & - & - & - & - & - & - & - & - & - & - \\
\hline Chroococcus turgidus (Kützing) Nägeli & 1 & $\mathrm{P}-\mathrm{B}, \mathrm{S}$ & - & aer & alf & hl & o & - & - & - & - \\
\hline Hyella fontana Huber \& Jadin & 2 & B & - & str & - & - & - & - & - & ot & - \\
\hline $\begin{array}{c}\text { Johannesbaptistia pellucida (Dickie) } \\
\text { W.R.Taylor \& Drouet }\end{array}$ & 4 & B & - & - & - & hbn & - & - & - & - & - \\
\hline Lyngbya sp. & 1 & - & - & - & - & - & - & - & - & - & - \\
\hline Oscillatoria sp. & 1 & - & - & - & - & - & - & - & - & - & - \\
\hline \multicolumn{12}{|l|}{ Euglenozoa } \\
\hline $\begin{array}{c}\text { Euglenaria caudata (Hüber) } \\
\text { A.Karnowska-Ishikawa, E.Linton \& } \\
\text { J.Kwiatowski }\end{array}$ & 3 & $\mathrm{P}$ & - & st-str & ind & $\mathrm{mh}$ & $\mathrm{a}$ & - & - & - & $6.0-7.6$ \\
\hline \multicolumn{12}{|l|}{ Bacillariophyta } \\
\hline $\begin{array}{c}\text { Achnanthes lanceolata (Brébisson ex } \\
\text { Kützing) Grunow }\end{array}$ & $1-3$ & P-B & warm & st-str & alf & $\mathrm{i}$ & $\mathrm{o}-\mathrm{x}$ & sx & - & - & $7.5-8.1$ \\
\hline $\begin{array}{l}\text { Achnanthidium minutissimum (Kützing) } \\
\text { Czarnecki }\end{array}$ & 1 & B & eterm & st-str & alf & $\mathrm{i}$ & $\mathrm{b}$ & es & ate & o-e & $4.3-9.2$ \\
\hline Amphora ovalis (Kützing) Kützing & 1 & B & temp & st-str & alf & $\mathrm{i}$ & $a-b$ & sx & ate & $\mathrm{e}$ & $6.2-9.0$ \\
\hline $\begin{array}{c}\text { Amphora pediculus (Kützing) Grunow ex } \\
\text { A.Schmidt }\end{array}$ & 1 & B & temp & st & alf & $\mathrm{i}$ & $\mathrm{o}-\mathrm{a}$ & sx & ate & $\mathrm{e}$ & 8.0 \\
\hline
\end{tabular}




\begin{tabular}{|c|c|c|c|c|c|c|c|c|c|c|c|}
\hline Cyclotella meneghiniana Kützing & 1 & P-B & temp & st & alf & hl & $\mathrm{o}-\mathrm{a}$ & $\mathrm{sp}$ & hne & $\mathrm{e}$ & $5.5-9.0$ \\
\hline Epithemia adnata (Kützing) Brébisson & 1 & B & temp & st & alb & $\mathrm{i}$ & b-a & sx & ats & me & $5.5-9.0$ \\
\hline Fragilariforma exigua (Grunow) M.G.Kelly & $2-6$ & - & - & str & acf & $\mathrm{hb}$ & o & - & ats & ot & - \\
\hline $\begin{array}{c}\text { Geissleria decussis (Østrup) Lange-Bertalot } \\
\text { \& Metzeltin } \\
\end{array}$ & 1 & $\mathrm{~B}$ & - & - & alf & $\mathrm{i}$ & $\mathrm{o}-\mathrm{a}$ & es & ats & me & - \\
\hline Gomphonema clavatum Ehrenberg & $3-6$ & $\mathrm{~B}$ & - & str & ind & $\mathrm{i}$ & $\mathrm{o}-\mathrm{b}$ & es & ats & me & - \\
\hline Gomphonema parvulum (Kützing) Kützing & $2-4$ & $\mathrm{~B}$ & temp & str & ind & $\mathrm{i}$ & $\mathrm{x}$ & es & hne & $\mathrm{e}$ & 4.5 \\
\hline $\begin{array}{c}\text { Gyrosigma acuminatum (Kützing) } \\
\text { Rabenhorst }\end{array}$ & 1 & $\mathrm{~B}$ & cool & st-str & alf & $\mathrm{i}$ & $\mathrm{o}-\mathrm{x}$ & - & ate & $\mathrm{e}$ & - \\
\hline $\begin{array}{c}\text { Halamphora coffeaeformis (C.Agardh) } \\
\text { Levkov }\end{array}$ & 1 & B & - & st-str & alf & $\mathrm{mh}$ & a & - & ate & $\mathrm{e}$ & - \\
\hline Mastogloia braunii Grunow & 1 & P-B & - & - & alf & $\mathrm{mh}$ & - & - & - & - & - \\
\hline Navicula exigua Gregory & 3 & $\mathrm{~B}$ & - & str & alf & $\mathrm{i}$ & $\mathrm{x}-\mathrm{O}$ & es & ats & e & - \\
\hline Navicula rhynchocephala Kützing & $3-6$ & $\mathrm{~B}$ & - & - & alf & $\mathrm{hl}$ & $\mathrm{b}$ & - & ate & o-e & $6.5-9.0$ \\
\hline Nitzschia commutata Grunow & 1 & B & - & - & - & $\mathrm{mh}$ & - & - & - & - & - \\
\hline Nitzschia filiformis (W.Smith) Hustedt & 1 & $\mathrm{~B}$ & - & st-str & alf & hl & $\mathrm{x}$ & es & hne & $\mathrm{e}$ & - \\
\hline Nitzschia fonticola (Grunow) Grunow & 2 & $\mathrm{~B}$ & - & st-str & alf & oh & o-b & - & ate & me & 7.7-7.95 \\
\hline Nitzschia gracilis Hantzsch & 1 & P-B & temp & st-str & ind & $\mathrm{i}$ & $\mathrm{o}-\mathrm{b}$ & $\mathrm{sp}$ & - & $\mathrm{m}$ & $6.0-8.0$ \\
\hline Nitzschia palea (Kützing) W.Smith & 2 & P-B & temp & - & ind & $\mathrm{i}$ & $\mathrm{o}-\mathrm{x}$ & $\mathrm{sp}$ & hce & he & $7.0-9.0$ \\
\hline Nitzschia sp. & 4 & - & - & - & - & - & - & - & - & - & - \\
\hline Nitzschia vermicularis (Kützing) Hantzsch & 1 & $\mathrm{~B}$ & - & str & alf & $\mathrm{i}$ & o & - & - & o-e & - \\
\hline Pinnularia erratica Krammer & 1 & $\mathrm{~B}$ & - & - & ind & $\mathrm{i}$ & - & - & - & - & - \\
\hline Pinnularia gibba Ehrenberg & 1 & $\mathrm{~B}$ & - & st-str & ind & $\mathrm{i}$ & $\mathrm{o}-\mathrm{b}$ & es & ate & o-e & - \\
\hline Pinnularia microstauron (Ehrenberg) Cleve & 1 & B & temp & st-str & ind & $\mathrm{i}$ & $\mathrm{x}$ & $\mathrm{sp}$ & ate & $\mathrm{o}-\mathrm{e}$ & - \\
\hline Rhopalodia gibba (Ehrenberg) Otto Müller & $3-6$ & $\mathrm{~B}$ & temp & - & $\mathrm{alb}$ & $\mathrm{i}$ & $\mathrm{x}-\mathrm{o}$ & es & - & - & $6.2-9.0$ \\
\hline Sellaphora bacillum (Ehrenberg) D.G.Mann & 2 & $\mathrm{~B}$ & - & st-str & alf & $\mathrm{i}$ & $\mathrm{o}-\mathrm{b}$ & sx & ats & me & $7.0-9.0$ \\
\hline \multicolumn{12}{|l|}{ Chlorophyta } \\
\hline Aphanochaete repens A.Braun & 6 & P-B & - & st & - & - & $\mathrm{b}$ & - & - & - & - \\
\hline Oedogonium sp. & $4-6$ & $\mathrm{~B}$ & - & - & - & - & - & - & - & - & - \\
\hline Stauridium tetras (Ehrenberg) E.Hegewald & 1 & $\mathrm{P}-\mathrm{B}$ & - & st-str & ind & $\mathrm{i}$ & $\mathrm{o}-\mathrm{a}$ & - & - & - & - \\
\hline \multicolumn{12}{|l|}{ Charophyta } \\
\hline Chara gymnophylla A.Braun & 6 & $\mathrm{~B}$ & - & - & - & - & - & - & - & - & - \\
\hline Closterium acerosum Ehrenberg ex Ralfs & 1 & P-B & - & st-str & ind & $\mathrm{i}$ & $\mathrm{a}-\mathrm{b}$ & - & - & me & - \\
\hline Cosmarium punctulatum Brébisson & $1-2$ & P-B & - & - & acf & $\mathrm{hb}$ & o & - & - & - & - \\
\hline Spirogyra sp. & 6 & $\mathrm{~B}$ & - & - & - & - & - & - & - & - & - \\
\hline Zygnema.sp. & 1 & B & - & - & - & - & $x-b$ & - & - & - & - \\
\hline
\end{tabular}

Note: Score, abundance scores. Ecological types [11] (Hab): B, benthic; P-B, planktonic-benthic, P- planktonic, S, soil. Temperature (T): cool, cool water inhabitant; temp, temperate waters inhabitant; eterm, eurytermic; warm - warm water inhabitant. Rheophility and Oxygenation (Rhe): str, streaming waters inhabitant; st-str, low streaming waters inhabitant; st, standing water inhabitant; aer, aerophilic. Acidity (pH): ind, indifferent; alf, alkaliphil; acf, acodophil; alb, alkalibiont. pH rank: pH amplitude in which species was found. Halobity (Sal): i, oligohalobious-indifferent; hl, oligohalobious-halophilous; hb, halophobious; mh, mesohalobious; hbn, halobiont. Saprobity (D): es, eurysaprob; sx, saproxen; sp, saprophil. Saprobity (Sap): o, oligosaprob; o-a, oligo-alpha-mesosaprob; o-x, oligo-xenosaprob; b-o, beta-oligo-mesosaprob; a-b, alpha-beta-mesosaprob; x, xenosaprob; x-o, xeno-oligosaprob; x-b, xeno-beta-mesosaprob; b, beta-mesosaprob; b-a, beta-alpha-mesosaprob; a, alpha-mesosaprob. Nitrogen uptake metabolism (Aut-Het) [22]: ats, nitrogen-autotrophic taxa, tolerating very small concentrations of organically bound nitrogen; ate, nitrogen-autotrophic taxa, tolerating elevated concentrations of organically bound nitrogen; hne, facultatively nitrogen-heterotrophic taxa, needing periodically elevated concentrations of organically bound nitrogen; hce, nitrogen-heterotrophic taxa, needing elevated concentrations of organically bound nitrogen. Trophic state (Tro) [22]: ot, oligotraphentic, m, mesotraphentic me, meso-eutraphentic; e, eutraphentic; he, hypereutraphentic o-e, oligo- to eutraphentic (hypereutraphentic). 


\subsection{Bio-indication of the Studied Pool Environment}

We use bio-indication methods in purpose to characterize of the pool water quality and ecosystem sustainable. We can characterize pool environment on the base of algal species ecology (Table 2) as inhabited by benthic algae, which prefer low alkaline, low saline water, medium saturated by oxygen with temperate temperature range (Figure 9). Algal community represents by autotrophic nutrition type species, which preferred medium organically enriched waters and indicate of Class of Water Quality II-III and eutrophic state of the pool (Figure 10). As can be seen in Table 2, the water quality defined by bio-indication is the same that show by water chemistry (Table 1 ).

We use Table 2 with Index saprobity $S$ value that we calculated on the base of species abundance scores and species-specific index s (after [21] model) and nitrate concentration (Table 1) data for ecosystem state index WESI calculation. Therefore, WESI is very high, always above the 1.0 that reflect not only high self-purification capacity of the pool ecosystem but also possibility to use all nutrients in the water. Can be seen that ecosystem was in good condition in rainy season during studied period despite the desiccation of each summer. This situation is contrary to that of the Upper Jordan River previously examined by us [5] where the pollution coming from the catchment area pollute the water more in winter than in summer. It can be assessed as a result of isolation of the studied pool from area with other anthropogenic activity (Figures 1,2).

\section{Conclusions}

The Ein Qinia pool as new studied locality in the high altitude habitat on the Golan Heights can be characterize on the base of water chemistry and bio-indication as artificial with semi-natural conditions, fresh, low alkaline with low organic polluted waters that inhabit by forty two algal species from which the streptophytes Chara gymnophylla (Characeae) were rather dominated and accompanied with large diatoms such as Gomphonema clavatum and Rhopalodia gibba, and green and charophyte algae that attached the Chara plants. Community changed in its green algae members from Spirogyra sp. as free floating form in 2008 and 2009 to Oedogonium sp. as attached form on charophytes plants in 2012. Our study let us to assume that decreasing of water level in the pool years by years is stressed charophytes because epiphytes attack the plants when the environment is in unfavorable condition whereas other algae in community are flourishing.

Under this stressed condition and high mountain insolation at water level lowest among observed Chara gymnophylla rarely formed gametangia as well as Chara vulgaris from highly insolated pools in Negev Desert $[23,24]$. Chara braunii C.C. Gmel. does not formed gametangia at high light intensity under laboratory culture conditions [25]. Therefore it may be concluded that excessive insolation could be adverse for gametangia formation of several Chara species.

The obvious difference in branchlet characters of specimens collected by Y. Lipkin and us in Ein Qinia rather pointes towards their sampling from different water bodies but also could be explained by successional replacement of $C$. vulgaris by $C$. gymnophylla in the same pool.

In contrary of cosmopolitan and common in many regions Chara vulgaris that represented in the Y. Lipkin collection from August 1967, Chara gymnophylla is distributed over the Mediterranean and Irano-Turanian phytogeographic realms and therefore can be used as distinct climatic indicator. It is important for the Eastern Mediterranean territory because this small area is represented by four phytogeographic realms and sharp change of altitude and climatic variables. The Ein Qinia pool ecosystem is impacted in summer as a result of water using and periodical desiccation. Therefore, the new charophyte locality in high mountain area of the Upper Jordan River basin can be monitored with using of chemical and bio-indication methods.

\section{Acknowledgements}

We thank Dr. Moti Tavassi for his assistance in the field trip. This work was partly funded by the Israeli Ministry of Absorption and Russian Foundation for Basic Research, project 14-04-31596-mol-a.

\section{REFERENCES}

[1] S. Barinova. The effect of altitude on distribution of freshwater algae in continental Israel, Current Topics in Plant Biology, Vol.12, 89-95, 2011a.

[2] R. E. Romanov, S. S. Barinova. The charophytes of Israel: historical and contemporary species richness, distribution, and ecology, Biodiv. Res. Conserv., Vol.25, 57-64, 2012.

[3] A. Pukacz, M. Pełechaty, A. Pełechata. The relation between charophytes and habitat differentiation in temperate lowland lakes. Polish Journal of Ecology, Vol. 61(1), 105-118, 2013.

[4] A. Horowitz. The Jordan Rift Valley, A.A. Balkema Publishers, Lisse, Exton, PA, 2001.

[5] S. S. Barinova, E. Nevo. The Upper Jordan River algal communities are evidence of long-term climatic and anthropogenic impacts, J. Water Resource and Protection, Vol.2, 507-526, 2010.

[6] A. S. Perry, R. Y. Perry. Effects in arid regions. In: Ecotoxicology and Climate, SCOPE, Published by John Wiley and Sons Ltd., 1989.

[7] S. Barinova, C.N. Solak, O. Erdoğan, R. Romanov. Algae and Zooplankton in Ecological Assessment of the Işıklı Lake, Turkey, Aquatic Biology Research, Vol.2, No.2, 23-35, 2014a. 
[8] S. Barinova, R. Romanov, C.N. Solak. New record of Chara hispida (L.) Hartm. (Streptophyta: Charophyceae, Charales) from the Işıklı Lake (Turkey) and critical checklist of Turkish charophytes, Natural Resources and Conservation, Vol.2, No.3, 33-42, 2014b.

[9] D.M. John, B.A. Whitton, A.J. Brook (Eds.). The freshwater algal flora of the British Isles: an identification guide to freshwater and terrestrial algae, Cambridge University Press, Cambridge, 2011.

[10] W. Krause. Charales (Charophyceae). Süßwasserflora von Mitteleuropa, vol. 18, Gustav Fischer Verlag, Stuttgart, 1997.

[11] S.S. Barinova, L.A. Medvedeva, O.V. Anissimova. Diversity of algal indicators in environmental assessment. Pilies Studio, Tel Aviv, (Book in Russian with tables and annotation in English), 2006.

[12] E. Swift. Cleaning Diatom Frustules with Ultraviolet Radiation and Peroxide, Phycologia, Vol.6, No.2-3, 161-163, 1967.

[13] S. S. Barinova. Morphology of connective spines in diatom algae of the genus Aulacoseira Thwaites, Paleontological Journal, Vol.31, No.2, 239-245, 1997.

[14] V. Sládeček. Diatoms as indicators of organic pollution, Acta Hydroch. Hydrob., Vol.14, 555-566, 1986.

[15] S. Barinova. Algal diversity dynamics, ecological assessment, and monitoring in the river ecosystems of the eastern Mediterranean, Nova Science Publishers, New York, USA, 2011b.

[16] http://en.climate-data.org/location/708476/
[17] W. Migula. Die Characeen Deutschlands, Österreichs und der Schweiz. In: L. Rabenhorst Kryptogamenflora. 2d ed., vol 5, pp. 765. Eduard Kummer, Leipzig, 1897.

[18] M. Galun. The Lichens of Israel, The Israel Academy of Sciences and Humanities, Jerusalem, 1970.

[19] algaebase.org

[20] G. Yehuda, S.S. Barinova, T. Krugman, T. Pavlicek, Y. Nov, E. Nevo. Microscale adaptive response of charophytes of the Negev Desert, Israel: species divergences by AFLP, Natural Resources and Conservation Vol.1, No.3, 55-64, 2013.

[21] V. Sládeček. System of water quality from the biological point of view, Ergebnisse der Limnologie, Vol.7, 1-128, 1973.

[22] H. Van Dam, A. Martens, J. Sinkeldam. A coded checklist and ecological indicator values of freshwater diatoms from the Netherlands, Netherlands J. Aquatic Ecol., Vol.28, 117-133, 1994.

[23] S. Barinova, R. Romanov. Unique charophytes locality in the Borot Loz Natural Reserve, Negev Desert, Israel, Discovery Nature, Vol.9, No.21, 33-41, 2015.

[24] S. Barinova, R. Romanov. How a new locality of algal community in the Negev Desert, Israel was formed, Expert Opin. Environ. Biol., Vol.4, No.2, 1-7, 2015.

[25] M. Sato, H. Sakayama, M. Sato, M. Ito, H. Sekimoto. Characterization of sexual reproductive processes in Chara braunii (Charales, Charophyceae), Phycological Research Vol.62, 214-221, 2014. 